\title{
11
}

\section{MIXED-INCOME HOUSING IN NEW YORK CITY}

\section{Achievements, Challenges, and Lessons of an Enduring Mayoral Commitment ${ }^{\top}$}

\author{
Alex F. Schwartz and Sasha Tsenkova
}

\section{Introduction}

New York City has long been a laboratory for mixed-income housing. For decades, in collaboration with nonprofit and for-profit organizations, New York has built thousands of housing units in mixed-income developments under many different programs and formats. New York is also distinctive among other cities in the United States in that its mixed-income housing is not contingent on the redevelopment of public housing or on inclusionary zoning. Whereas much, if not most, mixed-income housing built elsewhere in the country since the 1990s is connected to the demolition and redevelopment of public housing, often leading to a net loss of public housing, this is not the case for New York City. New York has had some form of inclusionary zoning since the 1980s, but it is a minor source of the city's mixed-income housing.

In this essay, we describe the breadth of mixed-income housing in New York City. We situate mixed-income housing within the history of New York's affordable housing programs, and emphasize the variety of forms it takes and the neighborhood contexts in which it occurs. We show how New York's mixed-income housing ranges from luxury housing that includes some units designated for lower-income households, to developments with a larger proportion of low- and moderate-income units and a much smaller share of market-rate units. We argue that New York City's case, including its experimentation with many forms of mixed-income housing, shows that:

- Mixed-income housing can be much more diverse in terms of its income composition, funding sources and programmatic design than one might presume from a reading of the literature.

- Mixed-income housing is an ordinary, even mundane, part of the city's landscape; notwithstanding occasional controversies sparked by particular buildings or programs, it is commonplace for people with widely varied incomes and other characteristics to reside in the same building or on the same block. In fact, the mixed-income quality of mixed-income housing may not be what defines or distinguishes the housing in the eyes of residents.

- Mixed-income housing nearly always requires government subsidy; the notion that income from market-rate units will fully subsidize the "affordable" units is rarely viable. 
- The city's chronic shortage of affordable housing and broad-based support for public investment in many forms of affordable housing may allow for more creative, ambitious and durable approaches to mixed-income housing than anywhere else in the USA.

We conclude with a brief discussion of lessons and unresolved questions about New York's experience with mixed-income housing and implications for policy and practice in the mixedincome field.

\section{The Relationship between Public Housing and Mixed-Income Housing in New York City}

In the rest of the United States, mixed-income housing is strongly associated with the redevelopment of public housing. Under HOPE VI and other programs, public housing authorities demolished more than 150,000 public housing developments, replacing many with mixed-income housing that includes a smaller number of public housing units and varying blends of other subsidized and market-rate housing, sometimes including owner-occupied housing (Chaskin and Joseph 2015; Gress et al. 2019; Vale and Shamsuddin 2017; Vale et al. 2018).

New York has not demolished any of its public housing developments, however; its two HOPE VI projects upgraded the physical plants and remained 100\% public housing.

New York's public housing encompasses aspects of mixed-income housing that are found in few other cities. First, many of New York's public housing developments have been home to households with a wider range of incomes than elsewhere. As with public housing in the rest of the country, New York's public housing accommodates many people with extremely low incomes. But unlike other places, New York's public housing has also attracted many people, including teachers and civil servants, with higher incomes. This attraction reflects the relatively high quality of many public housing developments at the time of their construction, their affordability and in many cases their proximity to transit and other urban resources (Bloom 2008). It also reflects the fact that public housing in New York City is widely dispersed, with developments located in 46 of the city's 59 community districts. While fewer moderate- and middle-income residents currently live in New York's public housing than in years past, they are still more prevalent in New York than in the public housing of other cities. For example, in 2018, wages were the most important source of income for $40 \%$ of New York's public housing residents, compared to an average of $29 \%$ in the ten next-largest housing authorities in the continental USA, and $40 \%$ of New York's public housing households earned at least $\$ 20,000$ annually, compared to $23 \%$ in that comparison group (U.S. Department of Housing and Urban Development 2019).

The second aspect of mixed-income public housing in New York City stems from the fact that many developments are situated in middle-class and affluent neighborhoods. While many public housing developments are located in relatively isolated low-income neighborhoods, others are found in the midst of some of New York's wealthiest areas (NYU Furman Center 2019). It is not hard to find public housing located next door or across the street from condominium towers, with apartments costing several million dollars each. For example, Amsterdam Houses is located across Amsterdam Avenue from Lincoln Center for the Performing Arts and the 54-storey Hawthorne Parke luxury rental building, where the average rent for apartments leased from January 2018 to June 2019 was $\$ 7,218 .^{2}$ The Chelsea Elliot Houses and Fulton Homes are located in close proximity to the Highline, the elevated park that has stimulated the construction of numerous luxury condos. Among them is 520 West 28th Street, designed by internationally renowned architect Zaha Hadid, where the sales price of apartments sold from 
January 2018 to March 2019 averaged \$10.3 million. ${ }^{3}$ New York University’s Furman Center found that nearly $60 \%$ of New York's public housing units, as of 2017, were located in gentrifying neighborhoods and an additional $27 \%$ in higher-income neighborhoods (NYU Furman Center 2019: 3). The close proximity of public housing with various tiers of market-rate housing illustrates what Vale and Shamsuddin (2017) have called the "mixing-around" form of mixed-income housing.

In an effort to generate much-needed revenue to help finance essential renovations and other capital improvements, New York City has started to lease vacant land on selected public housing campuses for the development of high-rise housing developments—some 100\% market-rate and others that combine luxury housing with units priced for lower-income households (New York City Housing Authority 2018). These efforts have been controversial, both because of the loss of open space, light, and views and because of fears that the development of market-rate housing will ultimately lead to the displacement of public housing residents (Kim 2019). That said, the fact that private developers will build luxury market-rate housing cheek by jowl with public housing underscores that public housing need not be demolished or downsized in order to make mixed-income communities possible.

\section{Mixed-Income Housing Produced under Mayoral Housing Plans}

Most of New York City's mixed-income housing originated from the various affordable housing programs launched by the city since the late 1980s. Starting with Mayor Koch's Ten-year housing plan of 1987, New York City has invested, after inflation, more than $\$ 18.9$ billion on the construction and preservation ${ }^{4}$ of more than 450,000 units of affordable housing. Every subsequent mayor, Democrat and Republican, has allocated hundreds of millions of dollars each year for this purpose (see Figure 11.1). The current mayor, Bill de Blasio, set a goal of building

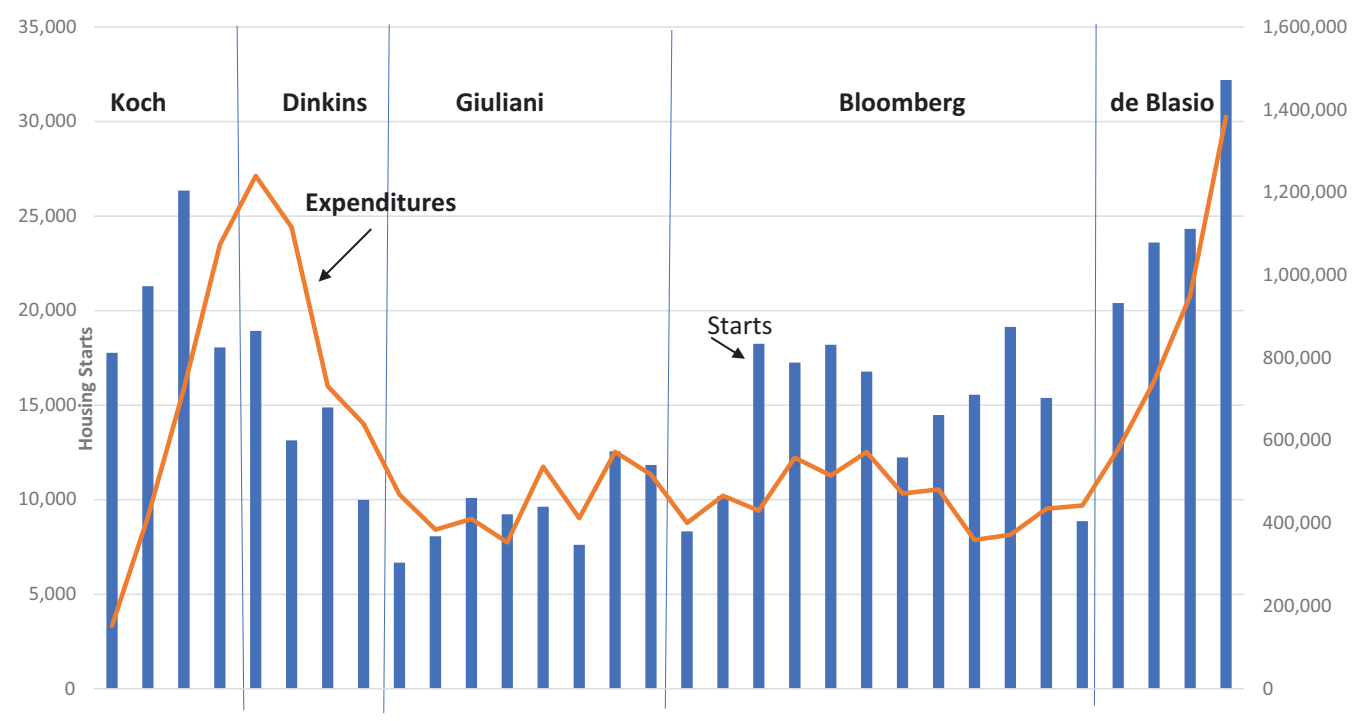

FIGURE 11.1 Capital Budget Expenditures (in Thousands of 2017 Dollars) and Affordable Housing Starts, 1987-2018.

Source: Mayor's Management Report and Comptroller's Budget Report. 
120,000 units and preserving 180,000 from 2014 to 2026; as of April 2019, the city had completed or started work on nearly 124,000 units (Schwartz 2019). De Blasio's initiative builds on Mayor Michael Bloomberg's 12-year New Housing Marketplace plan, which produced 165,000 affordable units.

New York's housing plans are assemblages of various programs that target different income groups and residents; they involve new construction, physical renovations, and the renewal of existing subsidies. The plans involve a range of partners, including for-profit housing developers, large nonprofit organizations, and smaller community-based organizations. The plans are funded through the city's capital budget (in the form of general obligation bonds), and also from tax-exempt and taxable private activity bonds issued by the city's Housing Development Corporation, federal Low-Income Housing Tax Credits, and other sources. The plans also make use of property tax abatements and inclusionary zoning, which provide private developers with financial incentives to allocate a portion of otherwise market-rate housing developments to lower-income occupancy. Under Mayor de Blasio, the city expanded its previous voluntary inclusionary zoning program with the establishment of mandatory inclusionary zoning in neighborhoods that complete a rezoning process to permit higher-density housing.

New York's housing plans have produced several forms of mixed-income housing. These vary from luxury apartment buildings in prime Manhattan neighborhoods that include some units for low- and/or moderate-income households, to developments situated in far less affluent communities that designate a higher percentage of units for such households. Virtually all mixed-income housing built over the past several decades involves some form of public subsidy. With the development of affordable housing often involving the purchase of expensive privately owned land, New York's housing programs increasingly include units for higher-income households to reduce the amount of public subsidy necessary to support low-income units.

As discussed below, the mixed-income housing produced under mayoral plans varies widely in terms of the share of housing allocated to various income bands and the degree to which the housing is affordable to very-low-income people. Some mixed-income programs, especially under Mayors Koch and Dinkins, designated most units to very-low-income households (earning up to $50 \%$ of the area median family income), including the formerly homeless, and allocated most of the rest to moderate- and middle-income families. Other programs produced predominantly market-rate housing, with a small share earmarked for low- or moderate-income tenants. Except for formerly homeless individuals and families, who almost always receive federal Housing Choice Vouchers or other rent subsidies, the lowest-income band in New York's mixed-income programs has ranged between $40 \%$ and $60 \%$ of average median income (AMI). Unfortunately, there is no information available on the racial and ethnic composition of the mixed-income housing produced in New York City.

Most of the mixed-income housing developed over the past three decades occasioned minimal, if any, opposition or controversy. However, this is less true today. Some opposition involves the real estate tax exemptions given to developers of ultra-luxury housing. The city has provided more than $\$ 1$ billion in exemptions for high-end housing, some but not all of which included affordable units. A more recent debate has centered around the rezoning of selected neighborhoods, mostly minority and low-income, for higher density (Schwartz 1999). Although these rezonings trigger mandatory inclusionary zoning that requires $20-40 \%$ of new units to be affordable to households at various income levels, critics contend that the affordability levels are not affordable enough given the low incomes of most residents, and that new market-rate development resulting from the rezoning will exacerbate the neighborhoods' 
affordability problems by stimulating gentrification (Greenberg 2019; Stein 2018; Tsenkova and Witwer 2011) and displacing low-income residents. Finally, a few mixed-income developments elicited public outrage by requiring the residents of the affordable units to enter the building through a separate door and barring them from using some of the buildings' amenities (Joseph 2019; Satow 2019).

\section{Selected Examples of Mixed-Income Housing in New York City}

\section{Luxury Housing with a Low- or Moderate-Income Component}

Private developers have built hundreds of market-rate apartment buildings in prime sections of Manhattan and, more recently, Brooklyn that include some amount of units for people with low or moderate income. Whether through below-market-rate financing, property tax exemptions, the opportunity to build at higher densities than otherwise allowed, or a combination thereof, developers have used these incentives to build apartment buildings that are mostly market-rate but reserve up to $25 \%$ of units for lower-income tenants. Sometimes these developments receive two or more such incentives. The affordable units are assigned to eligible households by lottery. The number of people who apply for affordable units in these mixed-income units typically exceed the number of available units available by a ratio of several hundreds to one (Navarro 2015; Satow 2019).

The so-called 80-20 program used tax-exempt bond financing to underwrite below-marketrate mortgages for housing that reserved $20 \%$ of units for households with incomes up to $60 \%$ of AMI, while the remaining 80\% were market-rate. Most buildings financed under the 80-20 program also received property tax exemptions. The 421a tax abatement program, created in the 1970s and modified several times to include buildings located in particular areas of New York City, ${ }^{5}$ required developers to designate a portion of units for low- or moderate-income tenants. An example is a project at 505 West 37th Street, Manhattan. Completed in 2009, the 835-unit doorman building is located in the Hudson Yards district on the far-west-side of Manhattan. Average market-rate rents in 2019 amounted to $\$ 3,533$, but 168 units are designated for lowincome households earning no more than $60 \%$ of AMI.

Generally, the affordable units within 80-20 and 421a buildings are intermixed with marketrate units, although units with the best views and other amenities usually are reserved for market-rate tenants. An exception is the small number of buildings that partitioned affordable units within separate sections. This issue became particularly contentious when news came out that a mixed-income building on the west side of Manhattan had installed separate entrances for market-rate and affordable units; the latter soon became known as the "poor door." The developer structured the building as two condominiums, each with its own entrance; in effect, a market-rate building situated next to a subsidized building. The physical segregation of income groups within a development, symbolized by separate entrances and amenities, raised concerns that this form of mixed-income housing can stigmatize lower-income residents and undermine the potential for community building across income groups (Joseph 2019; Navarro 2014).

In 2015, the city issued regulations requiring all entrances in mixed-income projects that receive tax exemptions or other subsidies to be open to all residents regardless of income (Moyer 2015). However, some mixed-income buildings prohibit residents of affordable units from using amenities (e.g., gyms, storage spaces) available to market-rate residents. The physical separation of income groups is characteristic of some luxury buildings that include a component of affordable units; it is much less common in other forms of mixed-income housing (Lamberg 2019). 


\section{Mixed-Income Housing with Larger Proportions of Lower-Income Units}

New York has sponsored many mixed-income developments that feature substantially larger percentages of low- and moderate-income units, with the top-income tier targeted to households earning much less than the market-rate tenants in 80-20 or 421a buildings. Because these buildings tend to designate more units for lower-income households, they often involve larger amounts of subsidy than 80-20 buildings and the like.

Mayor Koch's Construction Management Program. One of the earlier mixed-income programs instituted in New York City was the Construction Management program. Created as part of Mayor Koch's original initial ten-year plan, Construction Management involved the gut rehabilitation of large assemblages of vacant and highly deteriorated housing in the Bronx and Harlem. There were six Construction Management developments, each involving several hundred housing units (Schwartz and Tajbakhsh 2005). One of these projects was the New Settlement Apartments, sponsored by the Settlement Housing Fund, one of New York's largest nonprofit sponsors of low-income housing. Located in the Mount Eden section of the Bronx, the complex currently has 1,082 units. In all, 30\% of the units were originally allocated to formerly homeless families, who received Section 8 vouchers to cover the rent; $40 \%$ were allocated to low-income families; $20 \%$ to moderate-income families; and 10\% to households paying market-rate rents. Interestingly, the rents paid for the market-rate units were less than the rents paid by Section 8 vouchers. Every floor in the development includes households from all targeted income groups (Lamberg 2018).

The Construction Management program is one of the very few mixed-income initiatives in New York City to be examined from the tenants' perspective. In focus groups with residents in two Construction Management developments in the Bronx, Schwartz and Tajbakhsh explored resident satisfaction with the developments, awareness of the mixed-income character of the developments, and degree of social interaction within and across income categories. The researchers found that while the residents were fully aware of the mixed-income character of the developments, they did not consider it to be a defining feature. More salient were the affordability of the apartments, the location of the developments, the high physical quality of apartments, the responsiveness of property managers to their concerns, and the availability of on-site social services (Schwartz and Tajbakhsh 2005). Lamberg detailed the challenges in building and managing one of the Construction Management developments, as well as provided profiles of several long-time residents. Lamberg was the Executive Director of the Settlement Housing Fund, the sponsor of the development (Lamberg 2018).

Mayor Bloomberg's Mixed-Income Programs. These included three types of mixedincome projects: low- to moderate-income (80\% AMI or below), New HOP (81\% AMI or above), and 50/ $30 / 20$ mixed-income (replacing the previous 80-20 program). Developments were located mostly in Manhattan, to capitalize on demand for mid- and higher-income housing. Newly built mixedincome, affordable housing set an example for sustainability, design innovation, and institutional partnerships. The Hunter's Point South development on the Queens waterfront is the largest new affordable housing complex built in New York City since the 1970s. Envisioned as part of the City's 2012 Olympic bid, the first phase, co-developed by Related Companies, Phipps Houses, and Monadnock Construction, included 925 permanently affordable apartments and 17,000 square feet of new retail space, key infrastructure installations, a new five-acre waterfront park, and a new 1,100-seat school, while meeting national green building criteria (see Figure 11.2).

Another mixed-income project to come out of the Bloomberg era is Navy Green, co-developed by Dunn Development, L\&M Development Partners, and the Pratt Area Community Council. Consisting of 433 units in four multi-family buildings and 23 townhouses, 


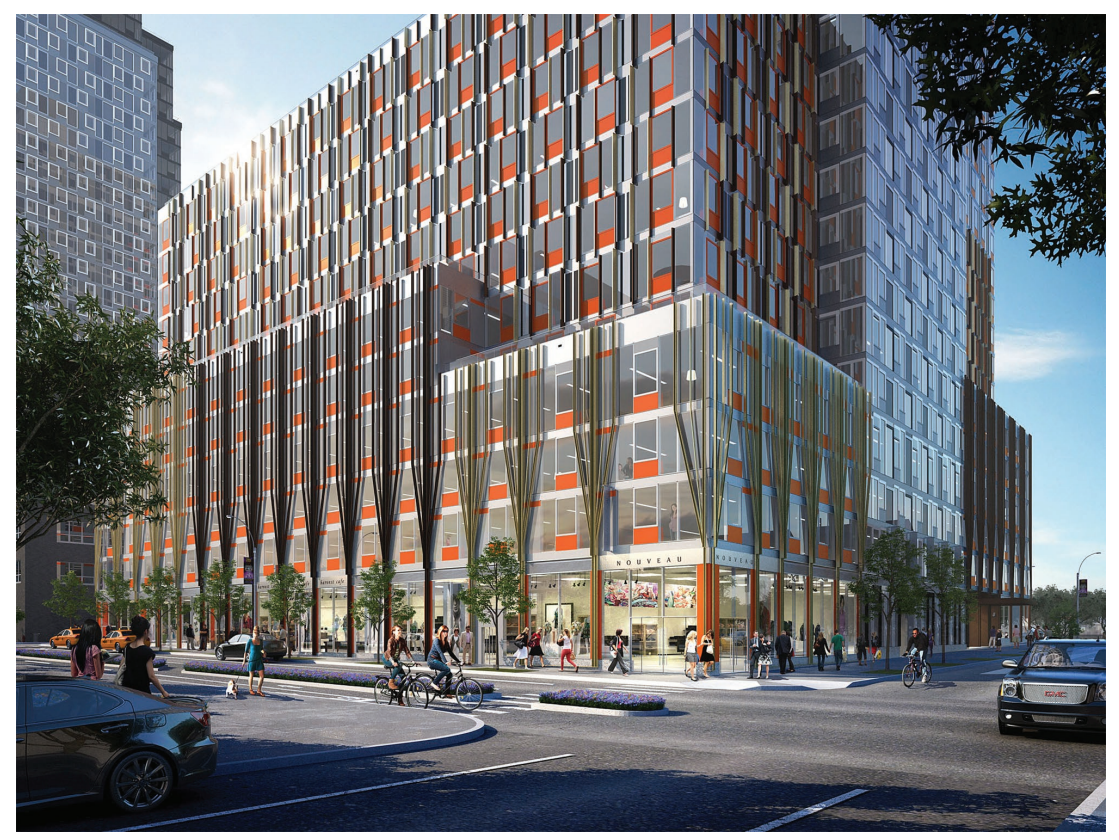

FIGURE 11.2 Hunter Point in New York City: The Largest Affordable Housing Development. Source: New York City Housing Development Corporation.
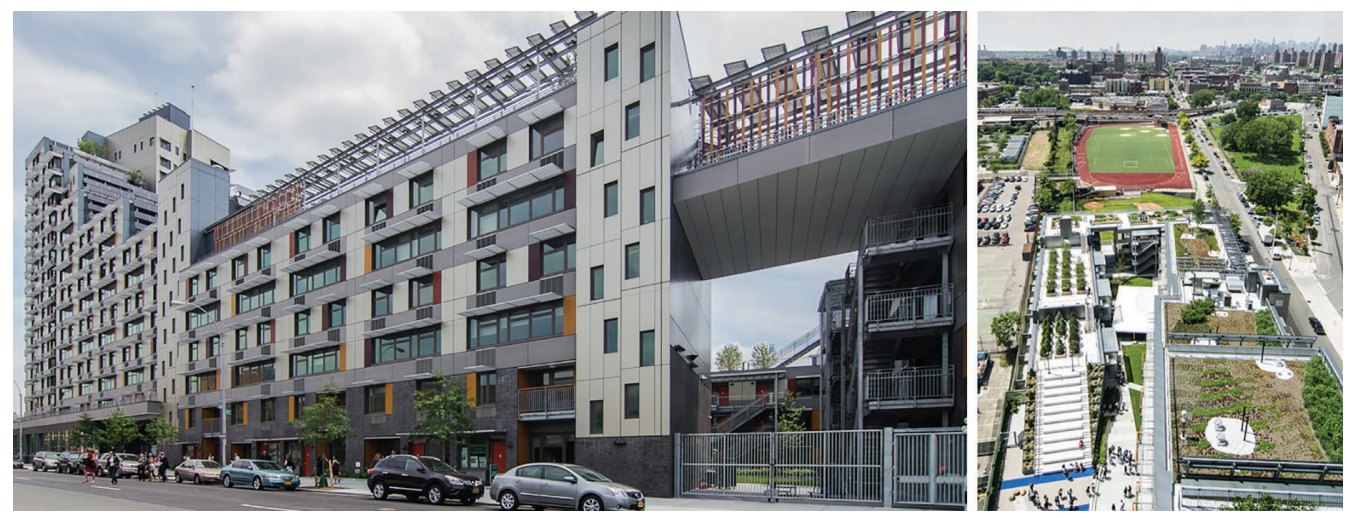

FIGURE 11.3 Via Verde Sustainable Mixed-Income Housing in New York City.

Source: New York City Housing Development Corporation.

the development combines supportive housing for formerly homeless families, owner-occupied housing, and rental housing for several income groups. Located across from the former Brooklyn Navy Yards, the complex also includes retail space, children's play area, open lawn, patios, and gardens.

Via Verde is a sustainable residential development, with 222 units of mixed-income housing in the South Bronx co-developed by Phipps Houses and Jonathan Rose Companies (see Figure 11.3). The project received the U.S Department of Housing and Urban Development's Award for Excellence in Affordable Housing Design in 2013. The ground floor features 11,000 
square feet of retail, a community health center, and live-work units. With a 66-kilowatt, building-integrated photovoltaic system, on-site cogeneration, green roof, community vegetable gardens, green interior finishes, rainwater harvesting, and drought-tolerant vegetation, the complex is LEED NC Gold certified (Tsenkova 2014).

Mayor de Blasio's Mixed-Income Housing Programs. Mixed-income programs rolled out by the de Blasio administration vary widely in terms of the top-and bottom-income levels that are targeted, the number of income tiers represented, and the distribution of units across income tiers. Two programs allow some units to be rented to market-rate tenants of any income, but three programs cap the maximum income at a specified percentage of the area median family income (from 100\% to 165\%). The lowest-income households eligible for the programs vary from formerly homeless people with incomes well below the poverty level to those earning $60 \%$ of AMI. The percentage of units allocated to the top-income tier varies from $30 \%$ to $75 \%$.

For example, the Extremely Low- and Low-Income Affordability (ELLA) program's income tiers include formerly homeless and other extremely low-income households. In one option, units must be allocated as follows: $10 \%$ to formerly homeless households, $10 \%$ to households earning up to $30 \%$ of AMI, $10 \%$ to households earning up to $40 \%$ of AMI, $10 \%$ to households earning up to $50 \%$ of AMI, and $30 \%$ to households earning up to $60 \%$ of AMI. Developers have the option of designating some or all of the remaining $30 \%$ of the units to households earning $70 \%$ to $100 \%$ of AMI; otherwise, they must be slated for households earning up to 60\% (Tsenkova and Schwartz 2019). In the second option, $30 \%$ of the units are allocated to formerly homeless households, $5 \%$ to households earning up to $40 \%$ of AMI, and 5\% to households earning up to 50\% of AMI. As with the first option, the remaining $60 \%$ must go to households earning up to $60 \%$ of AMI, although developers may allocate up to $30 \%$ of the units to households earning $70 \%$ to $100 \%$ of AMI. The city provides $\$ 130,000$ to $\$ 150,000$ in subsidy per unit, depending on the overall income mix in the development. City subsidies, federal Low-Income Housing Tax Credit, and property tax exemptions, combined with the cash flow from the higher-income units, make it financially viable to charge lower-income households affordable rents.

One of the first ELLA projects to be developed, by Dunn Development and L\&M Development Partners, is Livonia Commons. Located in the East New York section of Brooklyn, the development includes 278 apartment in four buildings. Fifty-one units consist of supportive housing for formerly homeless families who receive services on-site from two nonprofit organizations. More than half of the units are designated for families earning below $50 \%$ or $40 \%$ of AMI. The development also includes an arts center, a legal services office, a supermarket, a pharmacy, and other retail space (see Figure 11.4).

In the Mix and Match program, eligible developments must have a minimum of four income tiers. In all, $40 \%$ to $60 \%$ of the units must be affordable to households earning up to $60 \%$ of AMI, including at least $10 \%$ of units serving formerly homeless households. A minimum of $10 \%$ of units must be affordable to households earning 30\% to 50\% of AMI, and the remaining $40 \%$ to $60 \%$ of the units must be affordable to households earning up to $130 \%$ of AMI. Units receive $\$ 10,000$ to $\$ 225,000$ from the city's capital fund, depending on the income designation. Developments may also receive federal Low-Income Housing Tax Credit and property tax exemptions.

New York's Mandatory Inclusionary Housing Program. This mixed-income housing program allocates the majority of units to households able to pay market-rate rents. However, it also includes households with incomes that are lower than those permitted in nearly all other inclusionary zoning programs in the United States. Moreover, the program allocates a larger proportion of units to low- and moderate-income households, and it requires affordable units to remain so permanently (i.e., affordability is not time-limited). The program takes effect 


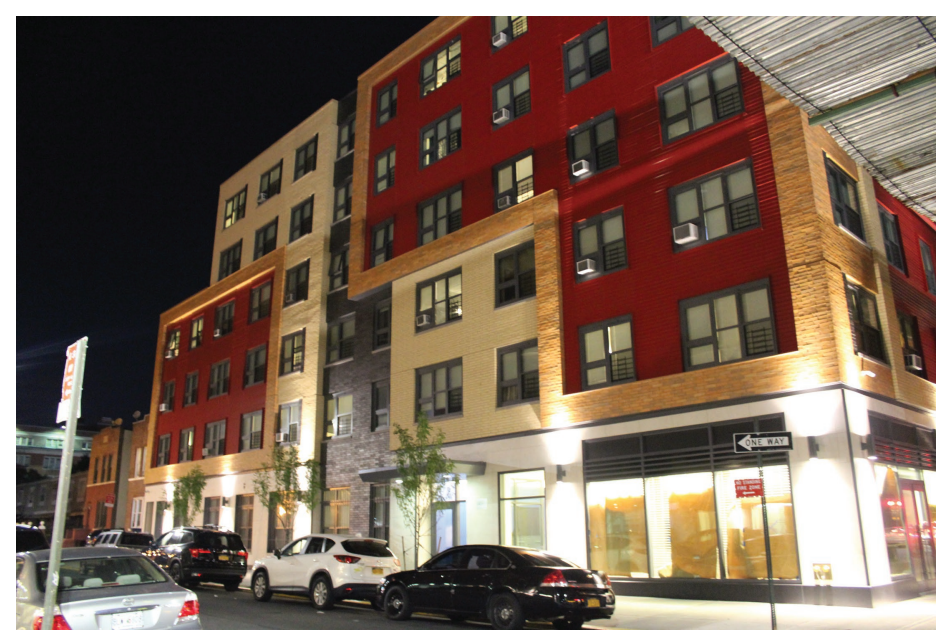

FIGURE 11.4 Livonia Commons.

Source: Dunn Development Corp.

whenever a neighborhood (or land parcel) is rezoned for higher densities. As of January 2019, five neighborhoods, starting with East New York, had been rezoned at higher densities, thereby effectuating mandatory inclusionary housing. Rezoning proposals were in process or anticipated for six additional neighborhoods. All but one of the neighborhoods with rezoning completed or in process are located outside Manhattan, and most are predominantly low-income neighborhoods (Kully 2019).

There are two basic options in the mandatory inclusionary housing program (Inclusionary Housing Program 2020). Under one, developers can designate $75 \%$ of total floor area for marketrate units, while the remaining $25 \%$ must go to households with an average income of $60 \%$ of AMI, including $10 \%$ that are allocated to households earning up to $30 \%$ of AMI. In the second option, $60 \%$ of the floor area is reserved for market-rate units, and the remaining $40 \%$ goes to households with an average income of $80 \%$ of AMI. If developers choose to build the affordable units off-site at a separate location, they must allocate an additional $5 \%$ of total floor area to households with an average income (depending on the option) of $60 \%$ or $80 \%$ of AMI. Mixedincome housing properties are underwritten so they do not require direct city subsidy, although they may be eligible for federal Low-Income Housing Tax Credit and city property tax exemptions. However, buildings financed under other subsidy programs may be, and are, located in rezoned neighborhoods.

Mandatory inclusionary housing is the most controversial of the de Blasio administration's affordable housing programs. Although it accounts for less than $4 \%$ of the 39,949 units of new construction started under the plan from 2014 through the first quarter of 2019, the program has attracted far more attention and criticism than all other aspects of the de Blasio plan (Schwartz 2019). One criticism is that even the lowest-rent apartments are unaffordable to most lowincome residents. This is because the rents are set in relation to the New York metro area's median family income, which is much higher than the median income in the neighborhoods that have been upzoned (Schwartz 2019). A second criticism is that, while the new buildings in the rezoned neighborhoods will provide some affordable units (notwithstanding the first criticism), the construction of taller, mostly market-rate buildings will exacerbate affordability problems by driving up land prices and rents throughout the neighborhood (Dulchin 2019; Savitch-Law 2017). The fact that the residents of most of the neighborhoods slated for rezoning tend to have 
low incomes and to be predominantly non-White has no doubt contributed to the plan's hostile reception. Some observers have suggested that the plan might have received more support if the city had also included more affluent and more White neighborhoods among those to be rezoned (Savitch-Law 2017). In any case, there is little evidence to show that the affordability pressures in the rezoned neighborhoods are any greater than in other neighborhoods of the city. On the other hand, rental pressures are acute in many neighborhoods, including many that have not been rezoned.

\section{Conclusions}

The New York City experience leads us to the following conclusions:

Mixed-income Housing Can Be a Financially and Socially Viable Form of Housing That Leverages the Private Sector to Finance a Limited Amount of Affordable Housing. The city's experience with public housing and, most especially, with the many housing programs that have been instituted under mayoral housing plans since 1986 illustrates the many ways in which mixed-income housing can be configured. It includes luxury housing located in prime Manhattan and Brooklyn neighborhoods in which about $20 \%$ of the units are designated for relatively low- and/or moderateincome households. It also includes developments located in lower-income neighborhoods with a larger percentage of low-income units and in which the rents charged to tenants at the top of the income tier tend to be considerably less than the market-rate rents of other mixed-income developments.

Mixed-income housing also has limitations as a vehicle for producing and financing affordable housing, however. The inclusion of market-rate units can generate a "cross-subsidy" to supplement the lower rents paid by lower-income residents. But only in limited circumstances is this cross-subsidy sufficient by itself to make the development financially viable. It may be sufficient when $80 \%$ of the units are reserved for market-rate units charging more than, say, $\$ 4,000$ per month, and when few, if any, affordable units are designated for households with extremely low incomes. Even in these cases, the developments receive low-interest financing and tax exemptions.

Ambitious Design That Set the Bar High in Terms of Sustainable Design and Green Elements Can Be Achieved. New York projects have won design awards for excellence, innovation, incorporation of public realm, and mixed-use components that contribute to neighborhood qualities (Honan 2019; Tsenkova 2014). Such experiences create an image of affordable housing projects that is remarkably different from the stigma associated with public housing of the 1960s.

Mixed-income Housing Can Take Many Forms and Be Situated in Many Different Types of Neighborhoods. Physically, mixed-income housing can involve rehabilitation of existing buildings as well as new construction. It can involve walk-up buildings of six stories to towers of 30 stories or more. It can be limited to single buildings or encompass multiple structures. Mixed-income projects can be entirely residential, and they can include various types of nonresidential components too, including retail, medical offices, schools, and libraries. As noted above, New York's mixed-income housing programs feature various combinations of income groups, with the representation of market-rate units varying from $80 \%$ to less than $20 \%$. And while it is true that mixed-income housing typically requires less subsidy in more affluent neighborhoods that command relatively high rents - rents that can "cross-subsidize" units occupied by low- and moderate-income households-with sufficient government subsidy, mixed-income housing also is viable in low-income neighborhoods. 
There Is No One Way to Finance Mixed-income Housing. Nearly all of the city's mixed-income developments have received some form of subsidy from New York City; very few have been underwritten entirely from private sources. Subsidies include property tax exemptions, grants, lowor zero-interest mortgages, federal Low-Income Housing Tax Credit, and project-based Housing Choice Vouchers. One challenge for financing mixed-income housing is the difficulty of providing subsidies for households with incomes that exceed the eligibility limits for the Federal Low-Income Housing Tax Credit (60\% of AMI) but are too low to afford market-rate rents.

\section{Notes}

1 This essay was previously published in What Works to Promote Inclusive, Equitable Mixed-Income Communities, eds. Mark L. Joseph and Amy T. Khare (Cleveland, $\mathrm{OH}$ : National Institute for Mixed Income Communities, 2020). To access the volume, go to https://case.edu/socialwork/nimc/resources/ what-works-volume.

2 The real estate service StreetEasy listed 57 apartments that were leased in this building from January 25, 2018 to June 6, 2019. The lowest rent was $\$ 3,295$ for a studio apartment and the highest was $\$ 16,900$ for a 3-bedroom unit.

3 Sales data from StreetEasy, which listed 28 open-market transactions during this period.

4 Preservation refers to physical renovation and other capital improvements of existing affordable housing and to commitments to extend or renew existing subsidies so that housing can remain affordable.

5 Originally Manhattan below 96th Street; later extended to parts of other boroughs.

\section{References}

Bach, V., and Waters, T. (2015) "Why We Need to End New York City's Most Expensive Housing Program: Time to End 421-a." New York: Community Service Society. Policy Brief (May), https://smhttp-ssl-58547.nexcesscdn.net/nycss/images/uploads/pubs/421aReportFinal.pdf

Bloom, N. D. (2008) Public Housing that Worked. Philadelphia: University of Pennsylvania Press.

Chaskin, R. J., and Joseph, M. L. (2015) Integrating the Inner City: The Promise and Perils of Mixed-Income Public Housing Transformation. Chicago, IL: The University of Chicago Press.

Dulchin, B. (2019) “Does Trickle-Down Affordability Justify the Mayor's Zoning Policy?” New York: Association for Neighborhood and Housing Development (blog, January 24), https://anhd. org/blog/does-trickle-down-affordability-justify-mayors-zoning-policy

Greenberg, M. (2019) “Tenants Under Siege: Inside New York City's Housing Crisis,” New York Review of Books (August 17), www.nybooks.com/articles/2017/08/17/tenants-under-siege-inside-new-yorkcity-housing-crisis/

Gress, T., Joseph, M. L., and Cho, S. (2019) "Confirmations, New Insights, and Future Implications for HOPE VI Mixed-Income Redevelopment,” Cityscape 21, 2: 185-212.

Honan, K. (2019) “New York City Selects Designers with Big Ideas for Small Lots," The Wall Street Journal (May 13), www.wsj.com/articles/new-york-city-selects-designers-with-big-ideas-forsmall-lots-11557793868

Joseph, M. L. (2019) "Separate but Equal Redux: Resolving and Transcending the Poor Door Conundrum," in The Dream Revisited: Contemporary Debates about Housing, Segregation, and Opportunity, eds. Ingrid Gould Ellen and Justin Peter Steil. New York: Columbia University Press, 292-294.

Kim, E. (2019) "Facing Opposition to Redevelopment Plan, City Establishes Working Group to Decide Future of NYCHA's Chelsea Complex," Gothamist (October 11), https://gothamist.com/news/facing-oppositionredevelopment-plan-city-establishes-working-group-decide-future-nychas-chelsea-complex

Kully, S. A. (2019) "De Blasio's Sixth Year in Office Could Feature Three Neighborhood Rezonings," City Limits (January 7), https://citylimits.org/2019/01/07/de-blasios-sixth-year-in-office-couldfeature-three-neighborhood-rezonings/

Lamberg, C. (2018) Neighborhood Success Stories: Creating and Sustaining Affordable Housing in New York. New York: Fordham University Press. 
Lamberg, C. (2019) "Housing Priorities: Quality Is More Important Than the Number of Entrances," in The Dream Revisited: Contemporary Debates about Housing, Segregation, and Opportunity, eds. Ingrid Gould Ellen and Justin Peter Steil. New York: Columbia University Press, 295-297

Moyer, J. W. (2015) “NYC Bans 'Poor Doors' - Separate Entrances for Low-Income Tenants,” Washington Post (June 30), www.washingtonpost.com/news/morning-mix/wp/2015/06/30/nyc-bans-poordoors-separate-entrances-for-low-income-tenants/

Navarro, M. (2014) “'Poor Door' in a New York Tower Opens a Fight over Affordable Housing," New York Times (August 26), www.nytimes.com/2014/08/27/nyregion/separate-entryways-for-new-yorkcondo-buyers-and-renters-create-an-affordable-housing-dilemma.html?searchResultPosition=2

Navarro, M. (2015) “88,000 Applicants and Counting for 55 Units in 'Poor Door' Building,” New York Times (April 20), www.nytimes.com/2015/04/21/nyregion/poor-door-building-draws-88000-applicantsfor-55-rental-units.html

New York City Department of Housing Preservation and Development (2010) New Housing Marketplace Plan. New York: New York City Department of Housing Preservation and Development.

New York City Department of Planning (2020) Inclusionary Housing Program. New York: New York City Department of Planning, www1.nyc.gov/site/planning/zoning/districts-tools/inclusionary-housing. page

New York City Housing Authority (2018). NYCHA 2.0: Part 1- Invest to Preserve. New York: New York City Housing Authority, www1.nyc.gov/assets/nycha/downloads/pdf/NYCHA-2.0-Part1.pdf

NYU Furman Center (2019) "How NYCHA Preserves Diversity in NYC's Changing Neighborhoods," http://furmancenter.org/research/publication/how-nycha-preserves-diversity-in-new-york8217schanging-neighborhoods

Satow, J. (2019) "Better Than the Powerball: For New Yorkers Looking for an Affordable Home, the Odds of Winning a Housing Lottery are 1 in 592," New York Times (January 11), www.nytimes.com/ 2019/01/11/realestate/better-than-the-powerball.html

Savitch-Law, A. (2017) “Will Rezoning Cause or Resist Displacement? Data Paints an Incomplete Picture," City Limits (January 10), https://citylimits.org/2017/01/10/will-rezoning-cause-or-resistdisplacement-data-paints-an-incomplete-picture/

Schwartz, A. (1999) "New York City and Subsidized Housing: Impacts and Lessons of the City's \$5 billion Capital Budget Housing Plan,” Housing Policy Debate 10, 4: 839-877.

Schwartz, A. (2019) "New York City's Affordable Housing Plans and the Limits of Local Initiative," Cityscape 21, 3: 355-388.

Schwartz, A., and Tajbakhsh, K. (2005) "Mixed-Income Housing," in Revitalizing the City: Strategies to Contain Sprawl and Revive the Core, eds. Fritz E. Wagner, Timothy E. Joder, Anthony J. Mumphrey, Jr., Krishna M. Akundi, and Alan F. J. Artibise. Armonk, NY: M.E. Sharpe.

Stein, S. (2018) "Progress for Whom, toward What? Progressive Politics and New York City's Mandatory Inclusionary Zoning Program," Journal of Urban Affairs 40, 6: 770-781.

Thaden, E., and Wang, V. (2017) "Inclusionary Zoning in the United States: Prevalence, Impact, and Practices” (Working Paper WP17ET1, September). Cambridge, MA: Lincoln Land Institute (September), www.lincolninst.edu/sites/default/files/pubfiles/thaden_wp17et1_0.pdf

Tsenkova, S. (2014) “Investing in New York's Future: Affordable Rental Housing in Mixed Income Projects," Plan Canada 53, 3: 32-40.

Tsenkova, S., and Schwartz, A. (2019) "Partnerships for Affordable Rental Housing in New York City," in Housing Partnerships, ed. Sasha Tsenkova. Calgary: University of Calgary, 37-46.

Tsenkova, S., and Witwer, M. (2011) "Bridging the Gap: Policy Instruments to Encourage Private Sector Provision of Affordable Rental Housing in Alberta," Canadian Journal of Urban Research 20, 1: 52-80.

U.S. Department of Housing and Urban Development (2019) Picture of Subsidized Households, www. huduser.gov/portal/datasets/assthsg.html

Vale, L. J., and Shamsuddin, S. (2017) "All Mixed Up: Making Sense of Mixed-Income Housing Developments," Journal of the American Planning Association 83, 1: 56-67.

Vale, L. J., Shamsuddin, S., and Kelly, N. (2018) "Broken Promises or Selective Memory Planning? A National Picture of HOPE VI Plans and Realities," Housing Policy Debate 28, 5: 746-769.

Waters, T. J., and Bach, V. (2013) Good Place to Work Hard Place to Live: The Housing Challenge for New York City's Next Mayor. New York: Community Service Society, www.cssny. org/publications/entry/good-place-to-work-hard-place-to-live 